\title{
ENTERPRISE STAKEHOLDERS PRIORITIZATION FOR THE PURPOSE OF MANAGEMENT OF REPUTATION RISK
}

\author{
Danuta SZWAJCA \\ Silesian University of Technology, Faculty of Organization and Management, Zabrze; \\ Danuta.Szwajca@polsl.pl, ORCID: 0000-0002-6517-6758
}

Purpose: The objective of this paper is to identify stakeholders categorization and prioritization tools, for the purpose of effective risk management of the enterprise.

Design/methodology/approach: Methods used in this paper include literature overview and deduction on the basis of concepts and approaches to the reputation risk management process analysis.

Findings: In the age of the Internet, social media and the growing competition in the global economy, enterprises are exposed to various types of risk. The most crucial among them is the reputation risk, which has the potential to generate significant financial and non-financial losses. Therefore, reputation risk management is not only a need, but also a necessity. A significant stage of management is the identification of reputation hazards, taking into consideration the gap between the expectations of stakeholders and the need to satisfy them. In this article methods of prioritizing enterprise stakeholders for the purposes of reputation risk management has been proposed. The hypothesis states, that prioritization of stakeholders allows to indicate the most important threats to the reputation and to formulate relevant tools for its protection.

Originality/value: Using mapping and sampling method to prioritize enterprise stakeholders for the purposes of reputation risk management.

Keywords: enterprise reputation, reputation risk, stakeholders.

Category of the paper: conceptual paper.

\section{Introduction}

In the modern economy, undergoing globalization, enterprises are exposed to multiple types of risks, that is market, financial, inflation, investment, innovation, currency exchange risk etc., which indicate the probability of incurring certain losses and experiencing disruptions in the business activity. In the last years, new risk category has taken the lead - the reputation risk. Reputation is the opinion on the company and its activity, held by different groups of stakeholders, constituting the basis of their decisions and choices. Establishing reputation is 
based on shaping and developing positive relations with the stakeholders, as well as meeting their needs and expectations (Dickinson-Delaporte, Beverland, Lindgreen, 2010). In the age, when intangible assets dominate on the market, reputation became one of the most valuable resources of an enterprise, as it can foster the establishment of long-term competitive advantage and goodwill (Gorczyńska, 2009). Deterioration of reputation or its loss not only generates measurable financial losses, experienced by BP, VW or Toyota, but also non-financial, longterm losses in image, which are difficult to be repaired (Szwajca, Rydzewska, Nawrocki, 2014).

According to global Aon research for the years 2015 and 2017, carried out in a two-year cycle among managers of enterprises from more than 30 industries, the reputation risk is indicated as the main threat to the functioning of enterprises in the modern world. It especially concerns such industries as banking, manufacture of consumer goods, hotel business, insurance, investment and finances, professional and personal services, telecommunication and data transfer, retail trade, transport services, as well as non-profit activities (Aon Global Risk Management Survey, 2017). Reputation risk is increased by the development of the Internet and modern media, which enable fast distribution of harmful, often untrue information on the company (Szwajca, 2017). In such conditions, it is important to manage reputation risk, in order to reduce the number and mitigate the results of potential hazards.

The need of reputation risk to be managed just like every other risk has been noticed not only by management theoreticians or risk management specialists, but also by managers. This was confirmed, among others, by survey questionnaires carried out by Deloitte and Forbes Insight in 2013 among 300 managers representing enterprises from basic industries and geographical regions (both Americas, Europe, Middle East, Africa, as well as Asia and Pacific). A majority of respondents $(88 \%)$ believed that reputation risk is a key strategic challenge for modern management (Deloitte, 2014 global survey on reputation risk, 2014).

The objective of this paper is to identify stakeholders categorization and prioritization tools for the purpose of effective risk management of the enterprise. The hypothesis states, that prioritization of stakeholders allows to indicate the most important threats to the reputation and effective tools for management of reputation risk. Methods used in this paper include literature overview and deduction on the basis of reputation risk management concept analysis, as well as a method of classification and prioritization of stakeholders.

The paper is the result of the project BK-231/ROZ1/2018 (13/010/BK_18/0029). 


\section{Reputation risk and sources of hazards}

Reputation risk of an enterprise can be defined as a likelihood of deterioration or loss of good reputation among stakeholders. According to Brady and Honey (2007), reputation risk is a gap between the expectations of stakeholders and the level of fulfillment of these expectations by the enterprise. Needs and expectations of various groups of stakeholders may not be met or might be met in an unsatisfactory way for various reasons, both attributable and non-attributable to the company. As a result, the source of reputation risk can be any event or incident that causes disruption in the functioning of an enterprise, that hinders the fulfillment of needs of any stakeholder group or makes it impossible. Due to this fact, reputation risk is often defined as "the risk of risks", as it can be triggered by any other type of risk, having its own causes, course and results (Tonello, 2007).

When analyzing the needs of particular stakeholders groups, one can indicate potential reputation risk sources (Table 1).

\section{Table 1.}

Expectations of the stakeholders and potential threats to the reputation

\begin{tabular}{|c|c|c|}
\hline $\begin{array}{c}\text { Stakeholders } \\
\text { group }\end{array}$ & Stakeholders' expectations & Potential risk events \\
\hline $\begin{array}{l}\text { Customers/ } \\
\text { consumers }\end{array}$ & $\begin{array}{l}\text { - guaranteed product / service quality } \\
\text { - value for money } \\
\text { - impeccable, professional service } \\
\text { - fair treatment } \\
\text { - interactivity } \\
\text { - transparent and available information }\end{array}$ & $\begin{array}{l}\text { - faulty product/improperly rendered } \\
\text { service } \\
\text { - prices too high, as compared with quality } \\
\text { - unmet service standards } \\
\text { - fraud and manipulation } \\
\text { - unfair advertising } \\
\text { - claims and complaints }\end{array}$ \\
\hline $\begin{array}{l}\text { Business } \\
\text { partners }\end{array}$ & $\begin{array}{l}\text { - effective negotiations } \\
\text { - meeting commitments } \\
\text { - financial credibility } \\
\text { - profitable cooperation } \\
\text { - business ethics } \\
\text { - financial, organizational support } \\
\end{array}$ & $\begin{array}{l}\text { - hard negotiations } \\
\text { - failure to meet the terms and conditions } \\
\text { of agreements } \\
\text { - insolvency / bankruptcy } \\
\text { - untimely payments } \\
\text { - unfair practices } \\
\end{array}$ \\
\hline $\begin{array}{l}\text { Investors and } \\
\text { shareholders }\end{array}$ & $\begin{array}{l}\text { - increase of company value } \\
\text { - high return on capital } \\
\text { - relevant investment decisions } \\
\text { - reliable and complex information } \\
\text { - abiding by the corporate governance rules }\end{array}$ & $\begin{array}{l}\text { - unattractive rate of return } \\
\text { - poor investment decisions } \\
\text { - fraudulent conversion of funds and } \\
\text { financial frauds } \\
\text { - hiding problems } \\
\text { - lack of reliable information } \\
\text { - manipulation of financial data }\end{array}$ \\
\hline Employees & $\begin{array}{l}\text { - employment guarantee } \\
\text { - safety at workplace } \\
\text { - development opportunity } \\
\text { - guarantee of social welfare } \\
\text { - abiding by employee rights } \\
\text { - fair treatment } \\
\text { - effective management }\end{array}$ & $\begin{array}{l}\text { - unfavorable agreements } \\
\text { - hazard in the workplace and accidents } \\
\text { - infringing employee rights } \\
\text { - failure to keep promises } \\
\text { - unfair practices } \\
\text { - incorrect decisions }\end{array}$ \\
\hline Media & $\begin{array}{l}\text { - equal treatment } \\
\text { - transparency } \\
\text { - reacting fast } \\
\text { - easy communication }\end{array}$ & $\begin{array}{l}\text { - discrimination } \\
\text { - hiding facts } \\
\text { - dishonesty } \\
\text { - hindered access to information }\end{array}$ \\
\hline
\end{tabular}


Cont. table 1.

\begin{tabular}{|l|l|l|}
\hline $\begin{array}{l}\text { Public } \\
\text { administration }\end{array}$ & $\begin{array}{l}\text { - abiding by the law } \\
\text { - transparency of activities } \\
\text { - effective communication } \\
\text { - tendency to cooperate }\end{array}$ & $\begin{array}{l}\text { - breaking the law } \\
\text { - fraud, embezzlement } \\
\text { - tax offenses }\end{array}$ \\
\hline $\begin{array}{l}\text { Local } \\
\text { communities }\end{array}$ & $\begin{array}{l}\text { - engagement in local social charitable and } \\
\text { educational projects } \\
\text { - environment protection } \\
\text { - fair treatment of people } \\
\text { - payment of local taxes }\end{array}$ & $\begin{array}{l}\text { - ignoring local needs } \\
\text { - harming the environment } \\
\text { - unethical conduct }\end{array}$ \\
\hline
\end{tabular}

Source: Own work based on: Defining and managing reputation risk. A framework for risk managers. Guide 2015. https://www.airmic.com/technical/library/defining-and-managing-reputation-risk; Ciepiela, M. (2014), Wpływ interesariuszy na zarządzanie przedsiębiorstwem. Rynek - Społeczeństwo Kultura, No. 3 (11), pp. 22-29.

It must be emphasized, that the threats, listed in the table, which are a result of failure to meet the expectations of a given stakeholders group, are transferred onto the other groups. We are dealing with a certain kind of "taint" of reputation and negative influence of a crisis on the subsequent groups of stakeholders (Figure 1).

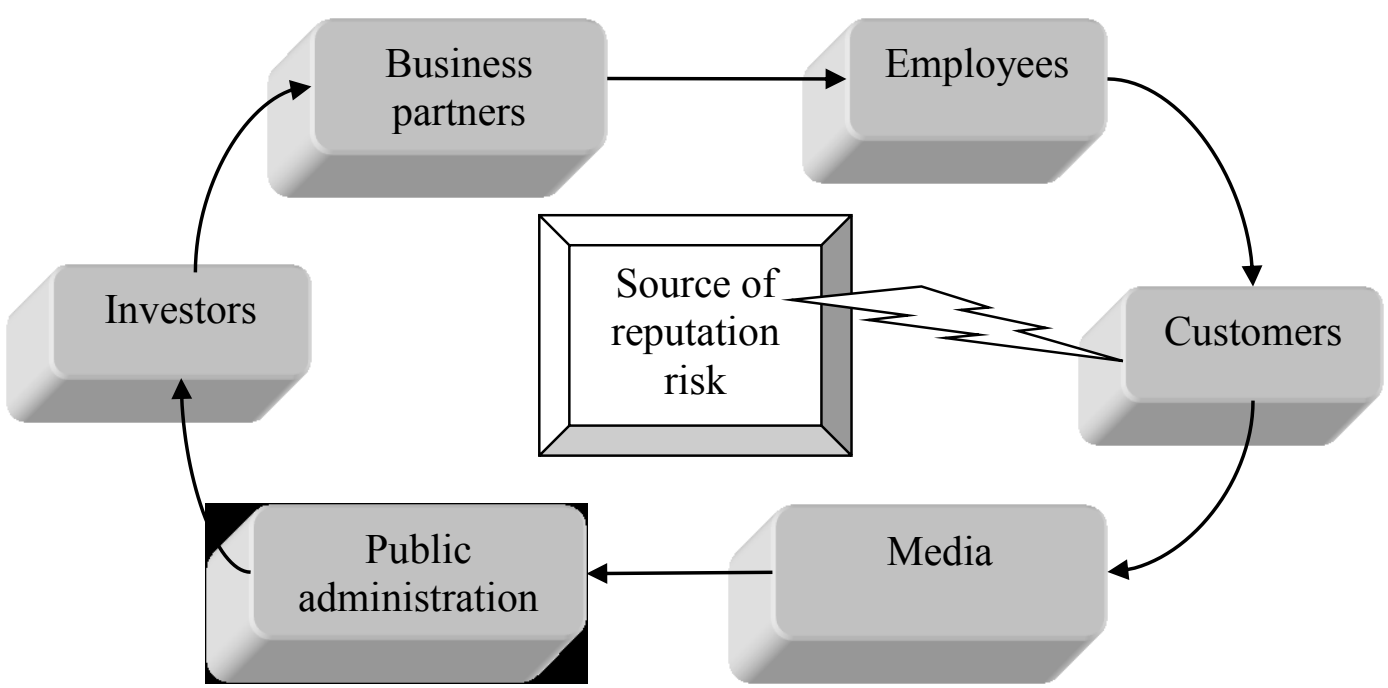

Figure 1. Path of reputation "taint" in a crisis situation. Source: Szwajca, D., Rydzewska, A., Nawrocki, T. (2014). Identyfikacji kosztów pogorszenia reputacji przedsiębiorstwa z perspektywy interesariuszy. Przeglad Organizacji, No. 4, p. 11.

For example, if a crisis was caused by a faulty product, the path of reputation taint begins with consumers expressing their dislike with the use of various media: press, television, radio and, most importantly, through social media. Unfavorable information reaches the public, is commented and shared, and the representatives of various administrative bodies launch their legal procedures. Then, investors may react, withdrawing their shares or selling company's shares on the stock exchange. Business partners may also react, by discouraging others from cooperation, and, as a result, potential partners may not be interested in relations with such enterprise. A consequence of these negative phenomena can be the deterioration of financial results, which will be felt by the employees in terms of their remuneration and perspectives of further employment. Dissatisfaction of employees may deepen the negative opinions of the customers. 


\section{Reputation risk management concepts}

Reputation risk management concepts are based on approaches to risk management in an enterprise. Risk management is a process covering several stages. Depending on the approach, there can be three, seven or even ten stages (Burnaby and Hass, 2009). Figure 2 presents a 4-stage approach.

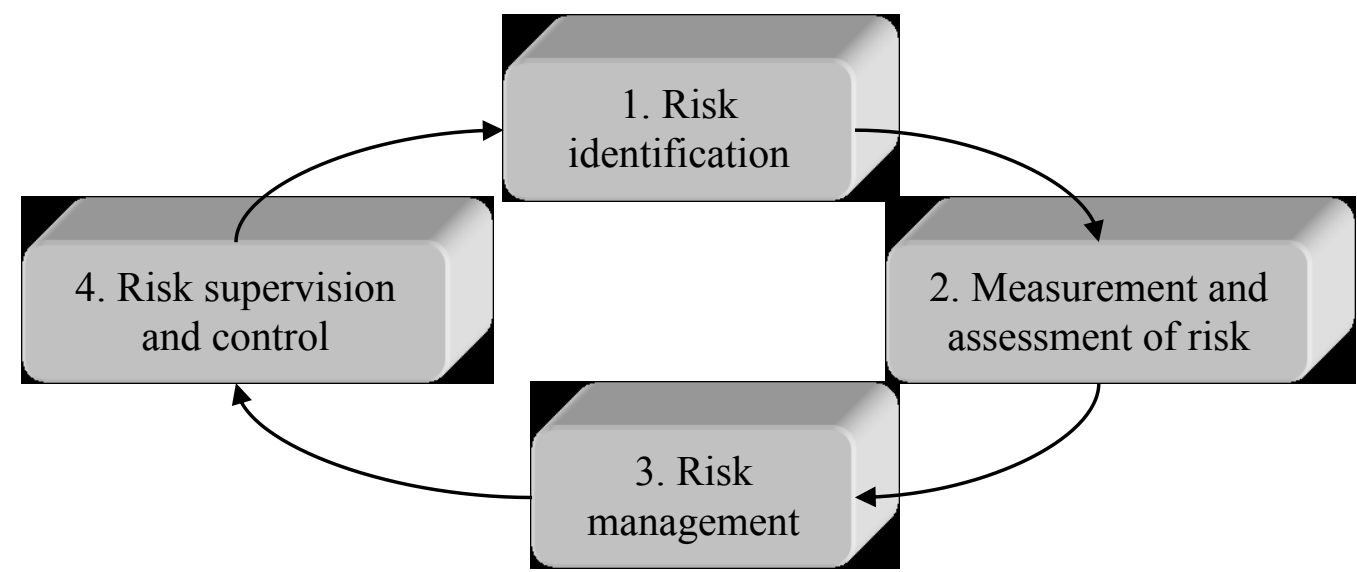

Figure 2. Risk management stages. Source: Own study based on: Jajuga, K. (2009). Zarządzanie ryzykiem. Warszawa: PWN, p. 15.

The first stage focuses on recognizing and naming each type of risk, which threatens the enterprise, providing their sources, causes and possible consequences. The second stage concentrates on the measurement and assessment of risk. Measurement, meaning risk quantification, is about determining the likelihood of its occurrence and the value of possible losses. According to the simplest formula, the size of each type of risk is calculated as a product of occurrence likelihood and the value of losses. On this basis, the assessment of identified risks is carried out, the result of which is hierarchization (prioritization). The next stage is about the development and implementation of risk management policy, meaning a system of activities aimed at minimizing the likelihood of risk occurrence and the possible losses. The process of risk management is concluded by the stage of risk supervision and control, within which the effectiveness of the used methods and procedures is assessed, and corrective steps are taken.

Table 2 presents three selected concepts of reputation risk management stages.

Although the number of stages varies, the sequence and scope of proposed activities is similar. Rayner and Larkin propose to start the reputation risk management process with the development of early warning system and identification of organizational unit responsible for its functioning, while Resnick's approach is more detailed and is similar to an audit. 
Table 2.

Selected reputation risk management concepts

\begin{tabular}{|c|c|c|}
\hline Resnick (2006) & Rayner (2003) & Larkin (2003) \\
\hline $\begin{array}{l}\text { 1. Identify reputational risk elements and } \\
\text { stakeholders } \\
\text { 2. Prioritize elements and stakeholders } \\
\text { 3. Inventory available reputation } \\
\text { information and identify information } \\
\text { gaps } \\
\text { 4. Design audit instruments and } \\
\text { methodology } \\
\text { 5. Conduct an audit } \\
\text { 6. Consolidate findings and report to } \\
\text { management. Gain management } \\
\text { acceptance of findings } \\
\text { 7. Develop a draft document with solutions } \\
\text { and possible implementation. Gain } \\
\text { management acceptance and support of } \\
\text { solutions } \\
\text { 8. Create and implement reputation } \\
\text { monitoring }\end{array}$ & $\begin{array}{ll}\text { 1. } & \text { Board / executive } \\
\text { commitment and tone- } \\
\text { setting } \\
\text { 2. } \\
\text { 3. Risk identification } \\
\text { 4. } \\
\text { 5. } & \text { Risk assessment } \\
\text { 5onitoring and reporting }\end{array}$ & 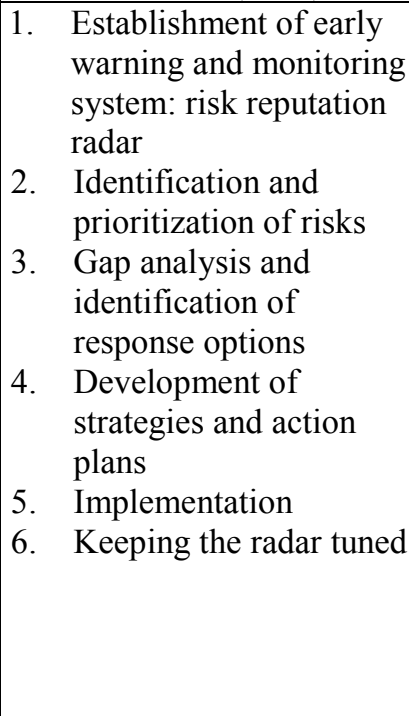 \\
\hline
\end{tabular}

Source: Resnick, J.T. (2006), Reputation Risk Management: A Framework for Safeguarding Your Organization 's Primary Intangible Asset, Opinion Research Corporation, pp. 11-12; Larkin, J. (2003), Strategic Reputation Risk Management. Palgrave MacMillan, New York, pp. 58-64; Rayner, J. (2003) Managing reputational risk. Curbing treats, leveraging opportunities. England: John Wiley \& Sons, pp. 49-57.

Due to the specifics of reputation risk, understood as a gap between the expectations of stakeholders and the level of fulfillment of these expectations, at the stage of risk identification, key groups of stakeholders and their expectations must be identified. At the stage of measurement and assessment of risk, the result of which is the hierarchization or risk, what is necessary is the classification and prioritization of stakeholders. The greatest risk will be associated with the failure to meet the expectations of the stakeholders crucial for the enterprise. Risk supervision and control concerns the measurement of reputation, meaning supervision over the stakeholders' opinions on the enterprise.

\section{Identification and prioritization of stakeholders}

According to Freeman (1984, p. 46), a promoter of stakeholders theory, stakeholders are individuals or groups that can influence the implementation of the organization's objectives, or the situation of whom is influenced by the organization implementing its objectives. When analyzing the definitions of different authors, it can be stated, that the stakeholders of an enterprise are entities (persons, formal and informal groups) (Szwajca, 2016, p. 42) that: 
- are or can be associated with the enterprise, that is, have specific relations with it,

- have legal or moral interests associated with the business activity,

- influence or can influence the decisions and activities of the enterprise,

- are subject or can be subject to the enterprise's influence,

- $\quad$ are the object of some responsibility of the enterprise.

Honey $(2009$, p. 3) states, that a stakeholder of an enterprise is any person who can help in its functioning or can damage it.

Stakeholders of the enterprise can be classified according to various criteria. Some of them are presented in Table 2 .

Table 2.

Selected criteria of stakeholders classification

\begin{tabular}{|l|l|}
\hline \multicolumn{1}{|c|}{ Criteria } & \multicolumn{1}{|c|}{ Stakeholders' types } \\
\hline $\begin{array}{l}\text { Importance of the enterprise } \\
\text { functioning }\end{array}$ & $\begin{array}{l}\text { Primary and secondary stakeholders; Core and peripheral/fringe } \\
\text { stakeholders }\end{array}$ \\
\hline $\begin{array}{l}\text { Influence on the financial results of } \\
\text { an enterprise }\end{array}$ & Key, emerging, minor \\
\hline Potential of hazard and cooperation & $\begin{array}{l}\text { Mixed blessing stakeholders, supportive stakeholders, non-supportive } \\
\text { stakeholders, marginal stakeholders }\end{array}$ \\
\hline $\begin{array}{l}\text { Number of held attributes (power, } \\
\text { legitimacy, urgency) }\end{array}$ & Definitive stakeholders, expectant stakeholders, latent stakeholders \\
\hline $\begin{array}{l}\text { Strength of influence and likelihood } \\
\text { of its use in practice }\end{array}$ & $\begin{array}{l}\text { Strong unaware, strong undecided, strong decided, weak unaware, } \\
\text { weak undecided, weak decided }\end{array}$ \\
\hline $\begin{array}{l}\text { Type of relation with a company } \\
\text { Consubstantial stakeholders, contractual stakeholders, contextual } \\
\text { stakeholders }\end{array}$ \\
\hline Access to information & Well-informed, selectively informed, unaware \\
\hline Attitude towards company & Positive, negative, neutral \\
\hline Influence on other stakeholders & Influential (opinion leaders), suggesting, neutral \\
\hline
\end{tabular}

Source: Own study based on: Lawrence, A. T., Weber, J. (2008). Business \& Society. Stakeholders, Ethics, Public Policy. New York: McGraw-Hill; Freeman, R. E., Harrison, J. S., Wics, A. C. (2007). Managing for Stakeholders. Survival, Reputation and Success. Yale University Press; Hart, S.L., Sharma, S. (2004). Engaging Fringe Stakeholders for Competitive Imagination. Academy of Management Executive, 18(1), pp. 7-18; Majchrzak, K. (2011). Zarzadzanie reputacja w przedsiębiorstwach sektora naftowego, Oficyna Wydawnicza SGH, Warszawa.

In the process of prioritization of stakeholders, a method of mapping can be used, which is applied widely in project management (Walker, Bourne, \& Shelley, 2008; Murray-Webster, \& Simon, 2006; Newcombe, 2003). The mapping procedure covers the following steps (Stakeholder Mapping, 2011):

1) stakeholders identification - making a list of stakeholders. There is no universal list of stakeholders, each company must draw up one, in accordance with the type and specifics of its business activity, localization, current objectives, competitive position etc.,

2) stakeholders analysis - classification and assessment of stakeholders from the point of view of the most important criteria, with the use of a rating scale (for example: low, average, high), 
3) stakeholders mapping - determining the position of stakeholders and placing them on a map consisting of several fields. Usually for every field there is a suggested activity towards groups of stakeholders placed in them (for example: focus on, inform, supervise, support),

4) stakeholders prioritization - indication of the most important groups of stakeholders, meaning the groups that hold the highest positions on the map. These groups require special treatment.

Figure 3 presents an example of stakeholders map of Millennium Bank Group, taking into account two criteria: influence of the Group on stakeholders and influence of stakeholders on the activity of the Group, while this influence can be low, medium or high.

After analysis and assessment of all identified stakeholders groups, they are located in relevant fields of the matrix (map). The prioritized groups are the ones, the influence of which on the business activity of the Group was assessed as high and which the Group significantly influences. Additionally, towards stakeholders occupying special positions on the map, a relevant course of action was proposed:

- Focus on the needs and expectations (high influence of the Group and high influence of the stakeholders on the Group),

- Informing about the activities of the Group (high influence of the stakeholders on the Group, low influence of the Group on the stakeholders),

- Supervision of activities (high influence of the Group and low influence of the stakeholders on the Group),

- Support of activities (low influence of the Group and low influence of the stakeholders on the Group).

The presented map indicates that priority stakeholders of Millennium Bank Group are, in order: employees, customers, shareholders, regulators and market supervision, as well as suppliers and social environment. It is their needs, expectations and activities that the Group should prioritize. 


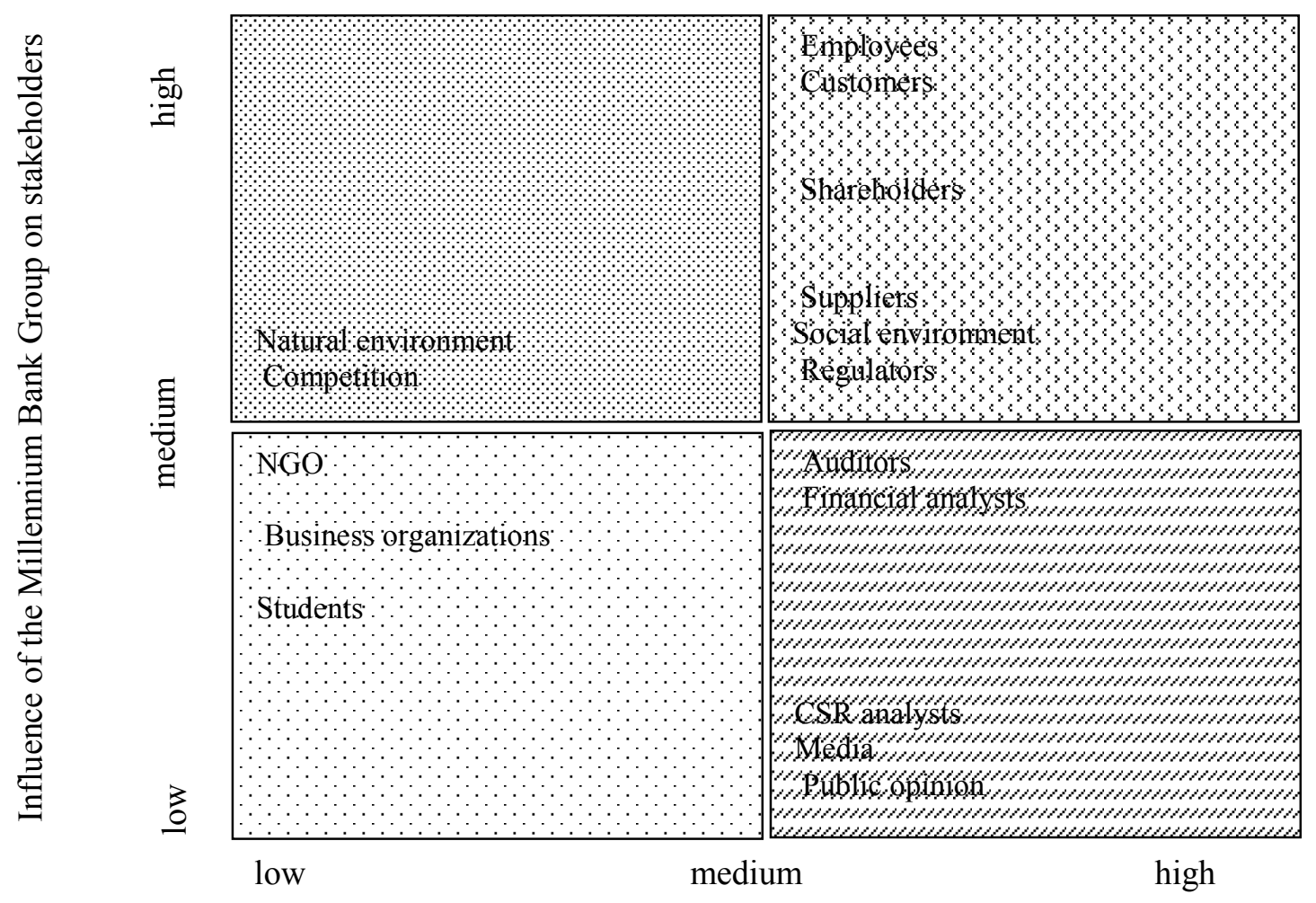

Stakeholders' influence on the activity of Bank Millennium Group

to concentrate $\lll$ to inform to monitor $\because \because \frac{\pi}{2}$ to support

Figure 3. Millennium Bank Group stakeholders map. Source: Own work based on: http://raportcsr.bankmillennium.pl/2013/pl/kluczowi-interesariusze/identyfikacja-interesariuszybanku.html.

Nevertheless, mapping as a stakeholders prioritization method for the purpose of reputation risk management has some limits. The created map is two-dimensional, so only two criteria of stakeholders assessment can be taken into account. Yet, there may be a number of important criteria, which would necessitate a creation of several maps. Each map may present a different position of a given stakeholders group, which would make the conclusion drawing more difficult. In such a situation, the two most important synthetic criteria should be used, and other should be excluded.

It seems that this problem can be solved by the random sampling method, which allows to take into account a larger number of criteria and order these criteria. This method comprises of the following stages:

1) Identification and compilation of a stakeholders list.

2) Selection and hierarchization of criteria of stakeholders importance assessment, i.e. assigning the criteria with relevant weighs (for example on a scale from 0 to 1 ).

3) Assessment, using a score system, of every stakeholders group from the point of view of the selected criteria (rating on a scale, for example from 1, meaning the lowest rating, to 10 , meaning the best rating). 
4) Calculation of the general assessment for particular stakeholders groups, being the sum of products of weighs and ratings within each criterion.

5) Making a stakeholders ranking, according to the obtained ratings.

An exemplary stakeholders assessment can be found in Table 3.

Table 3.

Stakeholders prioritization with the use of a sampling method-example

\begin{tabular}{|l|c|c|c|c|c|}
\hline \multicolumn{1}{|c}{$\begin{array}{c}\text { Stakeholders assessment } \begin{array}{c}\text { c } \\
\text { criteria }\end{array} \\
\end{array}$} & \multirow{2}{*}{ Weight } & \multicolumn{4}{|c|}{ Stakeholders groups } \\
\cline { 3 - 6 } & & Customers & Investors & Employees & Media \\
\cline { 3 - 6 } & Rating & Rating & Rating & Rating \\
\hline 1. Strength of influence & 0.8 & 8 & 9 & 7 & 5 \\
2. Likelihood of conflict & 0.6 & 8 & 7 & 9 & 8 \\
3. Influence on the decisions & 0.4 & 4 & 9 & 5 & 2 \\
4. Access to information & 0.3 & 3 & 9 & 8 & 8 \\
5. Potential of cooperation & 0.2 & 4 & 7 & 6 & 13.0 \\
\hline General rating & & 14.5 & 19.1 & 16.6 & 8 \\
\hline
\end{tabular}

Source: Own work.

As can be deducted from the table above, the highest rating was achieved by investors, and then, in order, by employees, customers and media. Here, it is worth noting, that in the process of prioritization one should take into account the differentiation of stakeholders within particular groups and the need of an in-depth prioritization (second level prioritization). Prioritization of stakeholders within each group (i.e. by determining the key customers, investors, vendors etc.) is also suggested by Resnick (2006, p. 14), since an enterprise is unlikely to have sufficient resources. Available resources must be focused among the stakeholders having the greatest impact on the business.

It must be noted, that even though the stakeholders assessment criteria are universal, it is not possible to create a universal hierarchy of stakeholders, even within a given industry or sector. Each enterprise must perform individual prioritization of its stakeholders, taking into account their own specifics, size, legal and organizational form, ownership structure, current competitive advantage, scope and place of activity (country, region), assumptions of the implemented strategy and external conditions. It is also worth emphasizing, that the defined hierarchy of stakeholders is not stable. The dynamically changing environment cause that the expectations, strength and power of stakeholders may change. Also new types of stakeholders, important for the prospective development of the enterprises, may emerge. Effective reputation risk management requires constant supervision of stakeholders, their expectations and ability to act, as well as reacting to changes that may necessitate the verification of current priorities. 


\section{Conclusion}

For many years, the reputation risk has been considered the most important hazard and challenge for modern enterprises. That is due to the fact, that the deterioration of reputation generates numerous losses, both measurable and those that are difficult to measure, the repair of which is expensive and time-consuming. Therefore, the need - and even the necessity to manage the reputation risk has been noticed by theoreticians and practitioners of management alike. Reputation is understood as an opinion of various groups of stakeholders on the enterprise and its activity, shaped on the basis of the level of fulfillment of their expectations by the company. As a result, reputation risk is defined as a gap between the expectations of stakeholders and the level and quality of their fulfillment.

Risk management covers four basic stages: risk identification, measurement and assessment, management, as well as supervision and control of risk. The result of the second stage is hierarchization (prioritization) of risk types identified in the first stage. Reputation risk refers to unmet expectations of various stakeholders groups or their improper fulfillment. Implementation of this stage in the reputation risk management process requires the prioritization of stakeholders - priority risks will be associated with the hazard of the lack of fulfillment of their expectations.

In the process of stakeholders prioritization, one can use mapping or sampling method. Stakeholders mapping, used primarily in the project management, allows not only for prioritization of stakeholders, but also for identification of the appropriate course of action towards specific groups. The created maps are two-dimensional, so only two criteria of the stakeholders assessment can be taken into account at the same time. Sampling method allows for simultaneous use of multiple criteria, that can be additionally hierarchized by assigning them with weights. Although stakeholders classification criteria are universal, it is not possible to indicate universal key stakeholders groups. Each enterprise must individually prioritize its stakeholders, taking into account its specifics and the conditions of business activity. Effective reputation risk management requires constant supervision of stakeholders, due to the fact that, as a result of dynamic environment, their expectations and possibilities can change, which can lead to the necessity of verification of their current hierarchy. 


\section{References}

1. Aon Global Risk Management Survey (2017). www.aon.com/2017-global-riskmanagement-survey/.

2. Brady A., Honey G. (2007). Corporate reputation: perspectives of measuring and managing a principal risk. London: The Chartered Institute of Management Accountants.

3. Burnaby, P., Hass, S. (2009). Ten steps to enterprise-wide risk management. Corporate Governance, 9(5), pp. 539-550.

4. Defining and managing reputation risk. A framework for risk managers. Guide 2015. https:/www.airmic.com/technical/library/defining-and-managing-reputation-risk.

5. Deloitte (2014). Global Survey on reputation Risk, October 2014. https://www2.deloitte.com/content/dam/Deloitte/pl/Documents/Reports/pl_Reputation_ Risk_survey_EN.pdf.

6. Dickinson-Delaporte, S., Beverland, M., Lindgreen, A. (2010). Building corporate reputation with stakeholders: Exploring the role of message ambiquity for social marketers. European Journal of Marketing, 44(11/12), pp. 1856-1874.

7. Freeman, R.E. (1984). Strategic management: A stakeholders approach. Boston: Pitman.

8. Freeman, R.E., Harrison, J.S., Wics, A.C. (2007). Managing for Stakeholders. Survival, Reputation and Success. Yale University Press.

9. Gorczyńska, A. (2009), Rola zasobów niematerialnych w decyzjach dotyczących międzynarodowej ekspansji przedsiębiorstwa. Kwartalnik Organizacja i Zarządzanie, 2, pp. 55-67.

10. Hart, S.L., Sharma, S. (2004). Engaging Fringe Stakeholders for Competitive Imagination. Academy of Management Executive, 18(1), pp. 7-18.

11. Honey, G. (2009). A Short Guide to Reputation Risk. England: Gower Publishing Limited.

12. http://raportcsr.bankmillennium.pl/2013/pl/kluczowi-interesariusze/identyfikacjainteresariuszy-banku.html.

13. Jajuga, K. (2009). Zarządzanie ryzykiem. PWN, Warszawa, p. 15.

14. Larkin, J. (2003), Strategic Reputation Risk Management. New York: Palgrave MacMillan.

15. Lawrence, A.T., Weber, J. (2008). Business \& Society. Stakeholders, Ethics, Public Policy. New York: McGraw-Hill.

16. Majchrzak, K. (2011). Zarzadzanie reputacja w przedsiębiorstwach sektora naftowego. Warszawa: Oficyna Wydawnicza SGH.

17. Murray-Webster, R., Simon, P. (2006). Making Sense of Stakeholder Mapping, PM World Today, November, VIII, 11.

18. Newcombe, R. (2003). From client to project stakeholders: a stakeholder mapping approach. Construction Management and Economics, 21, 8, pp. 841-848. 
19. Rayner, J. (2003). Managing reputational risk. Curbing treats, leveraging opportunities. England: John Wiley \& Sons.

20. Resnick, J. (2006). Reputation Risk Management: A Framework for Safeguarding Your Organization `s Primary Intangible Asset. Opinion Research Corporation, pp. 11-12.

21. Stakeholder Mapping (2011). https://www.bsr.org/reports/BSR_Stakeholder_ Engagement_Strategy_Briefing_Paper.pdf.

22. Szwajca, D. (2016), Zarzadzanie reputacja przedsiębiorstwa. Budowa i odbudowa zaufania interesariuszy. Warszawa: CeDeWu.

23. Szwajca, D. (2017). Media społecznościowe jako źródło ryzyka reputacyjnego przedsiębiorstwa. Studia Ekonomiczne, 322, pp. 230-242.

24. Szwajca, D., Rydzewska, A., Nawrocki, T. (2014) Identyfikacja kosztów pogorszenia reputacji przedsiębiorstwa $\mathrm{z}$ perspektywy interesariuszy. Przegląd Organizacji, 4, pp. 10-15.

25. Tonello, M. (2007). Reputation Risk. A Corporate Governance Perspective, Research Report. USA: The Conference Board, Inc., p. 22. ISBN: 0-8237-0906-X.

26. Walker, D.H.T., Bourne, L.M., Shelley, A. (2008), Influence, stakeholder mapping and visualization. Construction Management and Economics, 26(6), pp. 645-658. 